

\section{DISCLAIMER}

This report was prepared as an account of work sponsored by an agency of the United States Government. Neither the United States Government nor any agency Thereof, nor any of their employees, makes any warranty, express or implied, or assumes any legal liability or responsibility for the accuracy, completeness, or usefulness of any information, apparatus, product, or process disclosed, or represents that its use would not infringe privately owned rights. Reference herein to any specific commercial product, process, or service by trade name, trademark, manufacturer, or otherwise does not necessarily constitute or imply its endorsement, recommendation, or favoring by the United States Government or any agency thereof. The views and opinions of authors expressed herein do not necessarily state or reflect those of the United States Government or any agency thereof. 


\section{DISCLAIMER}

Portions of this document may be illegible in electronic image products. Images are produced from the best available original document. 
Printed in the United States of America. Available from National Technical Information Service

U.S. Department of Commerce

5285 Port Royal Road, Springfield, Virginia 22161

Price: Printed Copy $\$ 4.00$; Microfiche $\$ 3.00$

This report was prepared as an account of work sponsored by an agency of the United States Government. Neither the United States Government nor any agency thereof, nor any of their employees, nor any of their contractors, subcontractors, or their employees, makes any warranty, express or implied, nor assumes any legal liability or responsibility for any third party's use or the results of such use of any information, apparatus, product or process disclosed in this report, nor represents that its use by such third party would not infringe privately owned rights. 
Date of Issue: April 28, 1978

Distribution Category: UC-37

\title{
ACOUSTIC EMISSION INTRUSION DETECTOR
}

\author{
D. W. Carver
}

\author{
Instrumentation and Characterizatıon Uejártment \\ $Y \cdot 12$ Development Division
}

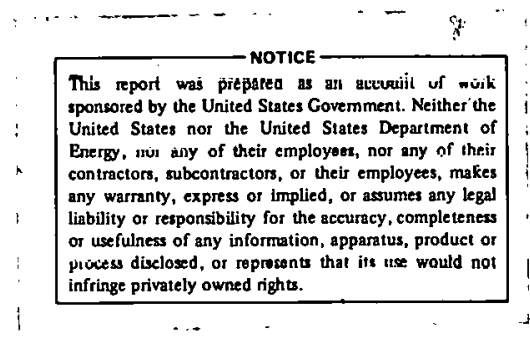

Oak Ridge Y-12 Plant

P. O. Box Y, Oak Ridge, Tennessee 37830

Prepared for the Department of Energy

Under US Government Contract W-7405-eng-26 


\begin{abstract}
In order to improve the security of handling special nuclear materials at the Oak Ridge $\mathrm{Y}-12$ Plant, a sensitive acoustic emission detector has been developed that will detect forcible entry through block or tile walls, concrete floors, or concrete/steel vault walls. A small, low-powered processor was designed to convert the output from a sensitive, crystal-type acoustic transducer to an alarm relay signal for use with a supervised alarm loop. The unit may be used to detect forcible entry through concrete, steel, block, tile, and/or glass.
\end{abstract}




\section{CONTENTS}

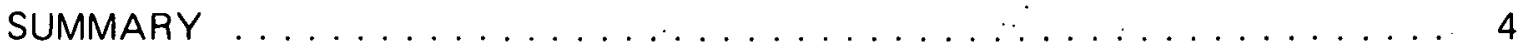

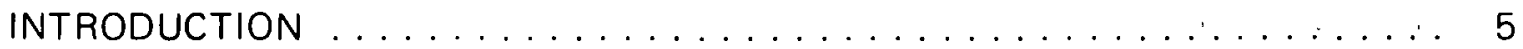

ACOUSTIC EMISSION DETECTOR $\ldots \ldots \ldots \ldots \ldots \ldots \ldots \ldots \ldots$

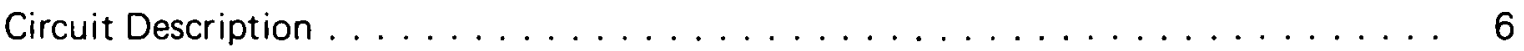

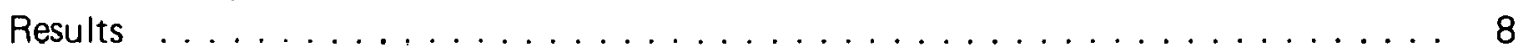




\section{SUMMARY}

As part of the Safeguards program at the $Y-12$ Plant, a sensitive acoustic emission device has been developed that will detect forcible entry through block or tile walls, concrete floors, or concrete/steel vault walls. A small, low-powered processor was designed to convert the transducer output to an alarm 'relay signal for use with a supervised alarm loop. The unit may be used to detect forcible entry through walls, ceilings, or floors of many different types of construction. 


\section{INTRODUCTION}

In response to an increased effort to improve the security of handling special nuclear materials at the Oak Ridge Y-12 Plant, (a) a number of intrusion alarm systems were evaluated and installed. However, a sensitive alarm with a negligible nuisance alarm rate usable on many different types of walls, floors, and ceilings was not commercially available. To fill this need, a sensitive acoustic emission detector was designed. The nuisance alarm rate of the detector has been extremely low during approximately nine months of use. Power requirements for the processor were minimized through the use of complementary metal oxide semiconductor (CMOS) amplifiers and integrated circuits. The standby (no alarmil) current required is less than 200 microamperes at 9.6 volts. The unit can operate from a small trickle-charged nickel/cadmium battery for days or weeks without primary power.

(a) Operated by the Union Carbide Corporation's Nuclear Division for the Department of Energy. 


\section{ACOUSTIC EMISSION DETECTOR}

\section{CIRCUIT DESCRIPTION}

The acoustic emission transducers which are used for the detector are sensitive, crystal-type transducers that are attached to a. smooth surface on the interior walls of the room or vault being monitored. A typical signal output from the transducer, due to a hammer-type blow on concrete or tile walls, is a damped sinusoid of approximately. 5 milliseconds duration at a frequency of 1100 to $1300 \mathrm{~Hz}$. The initial amplitude of the signal varies with the type of construction and distance from the disturbance to the detector, but it is typically 5 to 10 millivolts. When the transducer is attached to the steel in a reinforced wall, the output signal due to a hammer blow or metal saw stroke is a similar output of approximately 15 milliseconds duration at about $3500 \mathrm{~Hz}$. Typical outputs from the transducer for a disturbance in concrete or concrete/steel walls are illustrated in Figures 1 and 2.

A small, low-powered processor was designed to convert the transducer output to an alarm relay signal for use in conjunction with a supervised alarm loop. The processor, which is constructed on a single printed circuit board approximately 3 inches by 5

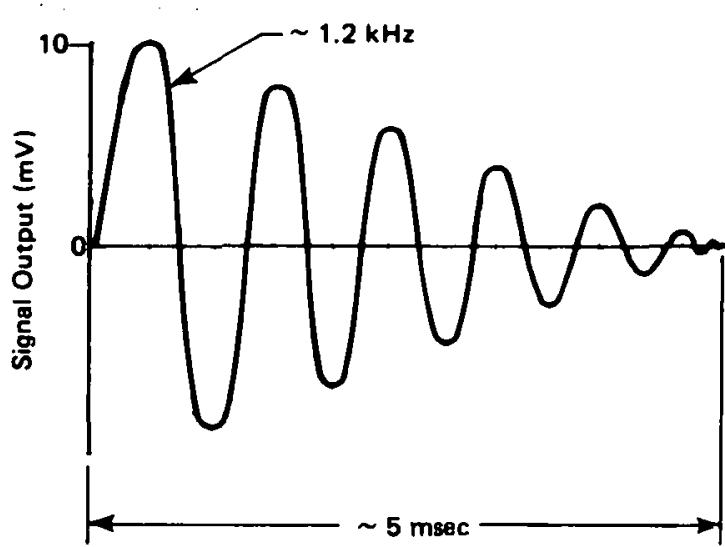

Figure 1. TYPICAL SIGNAL OUTPUT FOR A HAMMER BLOW ON VAULT CONCRETE. inches (Figure 3), consists of a 40-decibel maximum preamplifier staqe with a field=offect tranzistor iıpul followed by an adjustable (switch-selected) second amplifier stage of 20 decibel, maximum, for overall gain selection. In addition, the second amplifier rectifies the amplified transducer signal before routing the signal to the digital portion of the circuit. The low-frequency cutoff is fixed at about 800 $\mathrm{Hz}$. The amplifier is followed by a Schmitt trigger and timing circuit which rejects

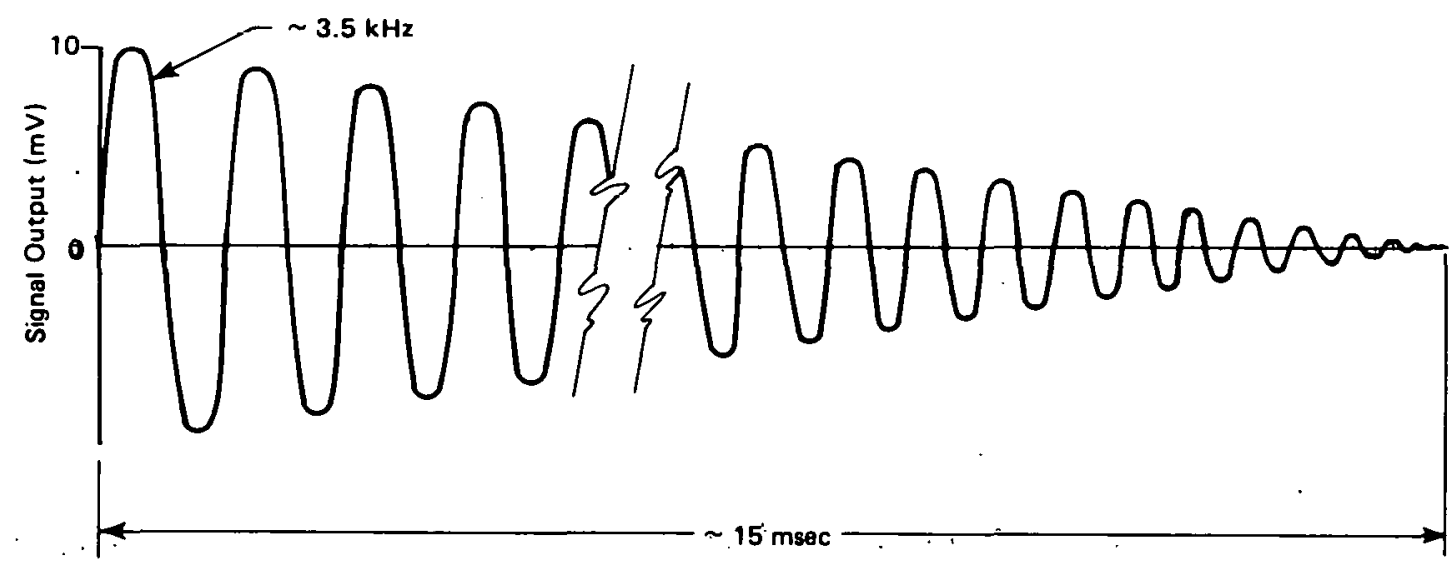

Figure 2. TYPICAL OUTPUT FOR A HAMMER BLOW OR METAL SAW STROKE ON VAULT STEEL. 


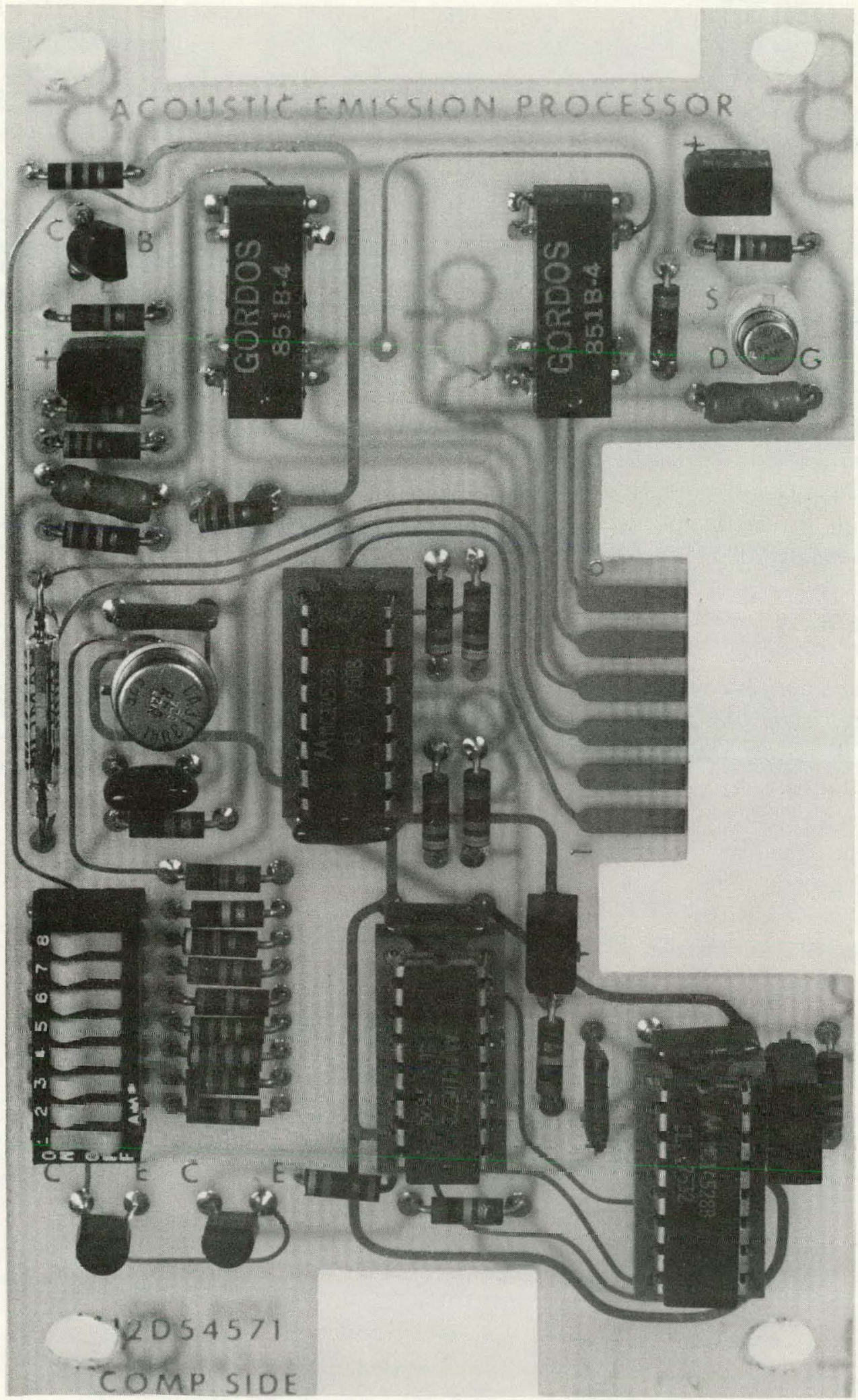

177552

Figure 3. PROCESSOR PRINTED CIRCUIT BOARD 
low-frequency periodic signals. When the disturbance detected by the transducer is determined to have sufficient amplitude and proper frequency, the signal is routed to pulse-shaping circuitry, followed by a relay driver. Miniature reed relays with isolated contacts are provided for the supervised alarm loop and a recorder, if needed. A block diagram of the circuit is given in Figure 4.

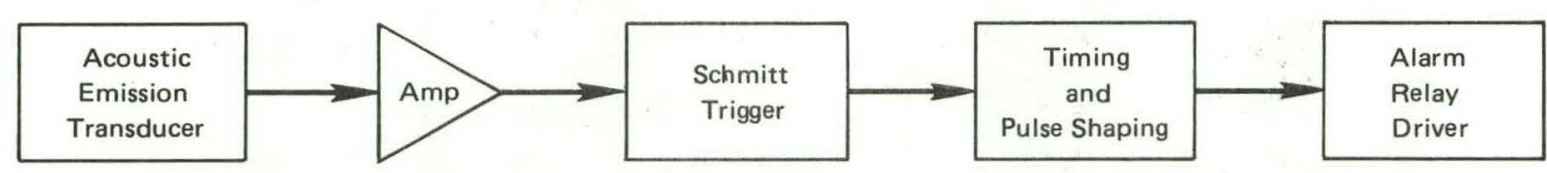

Figure 4. PROCESSOR CIRCUIT.

An audible signal is generated when an alarm condition is detected. The audible alert is provided primarily for sensitivity setup of the processor. The entire unit is housed in a 2 by 3 by 6 -inch box (Figure 5) which includes a tamper switch, recorder output connector, and a conduit fitting for the alarm and tamper-loop wiring. The standby current (no alarm) is approximately 200 microamperes at 9.6 volts.

\section{RESULTS}

Table 1

The detector has performed well on concrete, steel, block, tile, and glass. Table 1 gives the minimum impact momentum for an alarm to occur, using the least sensitive of eight gain settings for the unit. There were no known nuisance alarms, over a six-month period, from an

MINIMUM IMPACT MOMENTUM FOR ALARM

\begin{tabular}{lcc}
\hline $\begin{array}{c}\text { Wall/Vault } \\
\text { Construction }\end{array}$ & $\begin{array}{c}\text { Momentum } \\
(\mathrm{kg} \cdot \mathrm{m} / \mathrm{sec})\end{array}$ & $\begin{array}{c}\text { Distance to } \\
\text { Detector } \\
(\mathrm{m})\end{array}$ \\
\hline Tile Block & 0.3 & 4.0 \\
Concrete Block & 2.6 & 4.0 \\
Steel-Reinforced Concrete & 5.3 & 4.0 \\
\hline
\end{tabular}
installation consisting of eight detectors. More recently, an installation of two detectors has produced no nuisance alarms for a period of three weeks. 


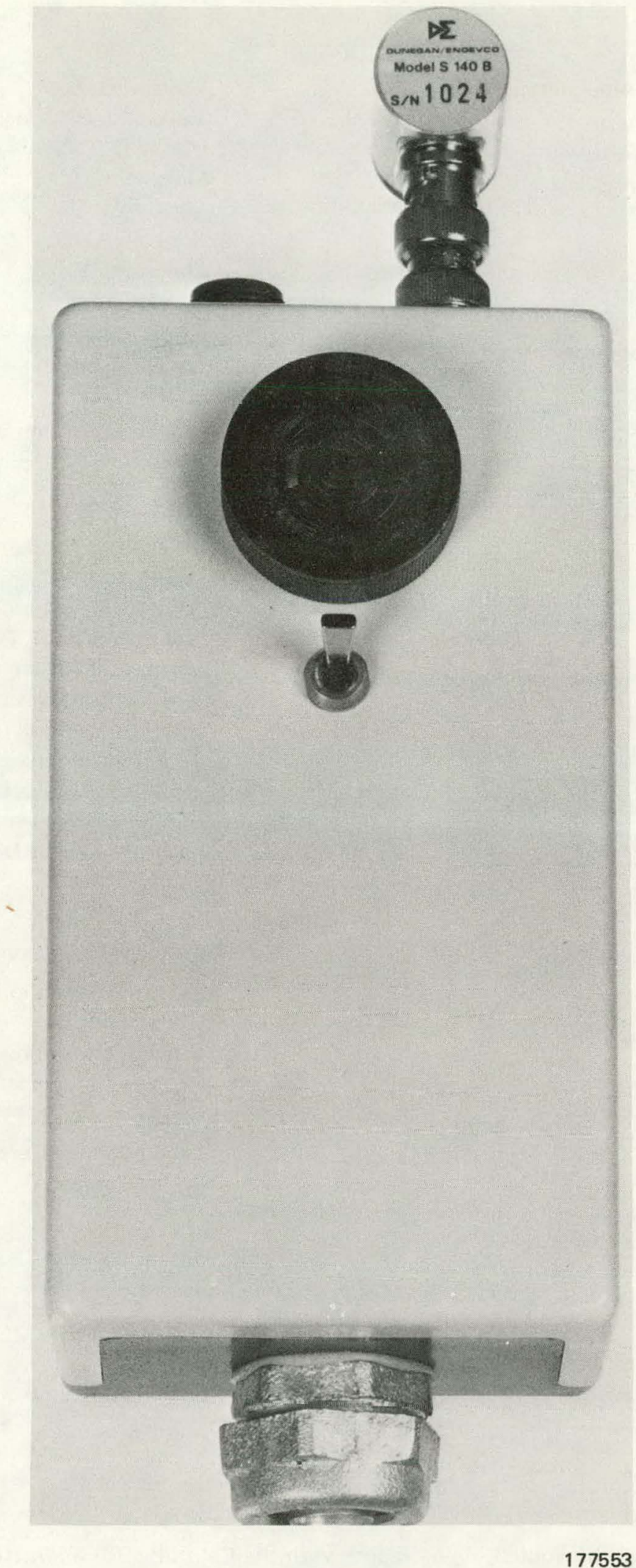

Figure 5. ACOUSTIC EMISSION DETECTOR. 


\section{Distribution}

Department of Energy - Albuquerque

Vespe, V. C.

Department of Energy - Oak Ridge

Hickman, H. D.

Leed, R. E.

Zachry, D. S., Jr

\section{Lawrence Livermore Laboratory}

Nelson, W. E.

Technical Information Division Library

Los Alamos Scientific Laboratory

Hoyt, H. C.

Library Services

Oak Ridge Gaseous Diffusion Plant

Stief, S. S.

Wilcox, W. J., Jr

Oak Ridge National Laboratory

Weir, J. R., Jr

Oak Ridge Y-12 Plant

Affel, R. G.

Armstrong, R. C.

Bernander, N. K.

Bowers, G. L.

Bostock, D. J.

Briscoe, O. W.

Burditt, R. B.

Carver, D. W. (10)

Dagley, R. L.

DeMonbrun, J. R.

Dodson, W. H.

Duggan, H. G.

Evans, G. W.

Foulk, D. L.

Fraser, R. J.

Jackson, V. C.

Jones, F. W.

Kahl, K. G.

Keith, A.

Kite, H. T. (50)
Marrow, G. B.

Martin, W. R./Googin, J. M.

Mason, D. L./Schreyer, J. M.

McLendon, J. D.

Mills, J. M., Jr

Oliphant, G. W.

Phillips, L. R.

Ramsey, W. E.

Rhew, J. E.

Smith, H. F., Jr

Smith, R. D.

Smith, W. E.

Stephens, A. E. (5)

Stoner, H. H.

Tewes, W. E.

Thompson, W. H., Jr

White, J. C.

Whitson, W. K.

Williams, R. D.

Yaggi, W. J.

Y-12 Central Files (master copy)

$\mathrm{Y}-12$ Central Files (route copy)

$Y-12$ Central Files ( $Y$-12RC)

Y-12 Central Files (5)

Paducah Gaseous Diffusion Plant

Bewley, H. D.

Sandia - Albuquerque

Mail Service Section

Sandia - Livermore

Technical Library

Union Carbide Corporation - New York

Tinsley, S. W.

In addition, this report is distributed in accordance with the Category UC-37, Instruments, as given in the USERDA Standard Distribution Lists for Unclassified Scientific and Technical Reports, TID-4500. 